\title{
EFEK HEPATOPROTEKTOR EKSTRAK ETANOL DAUN GALING (Cayratia trifolia L.Domin) PADA TIKUS PUTIH (Rattus norvegicus)
}

\author{
Muhammad Ilyas $\mathrm{Y}^{1^{*}}$, Ayu Muthmainnah ${ }^{2}$, Parawansah ${ }^{3}$ \\ Akademi Analis Kesehatan Kendari \\ Akademi Farmasi Bina Husada Kendari \\ Fakultas Kedokteran Universitas Halu Oleo Kendari ${ }^{3}$ \\ Email : ilyasyusufmuhammad.apt@gmail.com
}

\begin{abstract}
ABSTRAK
Penyakit hati adalah jenis penyakit yang berbahaya dan masih tergolong tinggi di Indonesia. Salah satu cara untuk mengetahui kerusakan hati dengan mengukur aktivitas enzim SGOT dan SGPT. Salah satu bahan alam yang berpotensi memiliki efek hepatoprotektor adalah tumbuhan Galing (Cayratia trifolia L.Domin) dan telah dilakukan penelitian bahwa tumbuhan Galing mengandung senyawa flavonoid yang berpotensi sebagai antioksidan. Tujuan penelitian adalah untuk mengetahui efek hepatoprotektor dan dosis yang efektif dari ekstrak etanol daun Galing pada tikus putih yang diinduksi paracetamol dosis toksik. Jenis penelitian adalah eksperimental laboratorium, dengan desain Rancangan Acak Lengkap (RAL) dan menggunakan 15 ekor tikus puth yang dibagi dalam 5 kelompok perlakuan dengan tiga kali pengulangan yang diinduksi dengan paracetamol dosis toksik setelah pemberian ekstrak. Berdasarkan hasil penelitian menunjukkan bahwa pemberian ekstrak etanol daun galing dengan dosis 300 $\mathrm{mg} / \mathrm{kg} \mathrm{BB}, 400 \mathrm{mg} / \mathrm{kg} \mathrm{BB}$, dan $500 \mathrm{mg} / \mathrm{kg}$ BB memberikan efek hepatoprotektor dengan mencegah peningkatan kadar SGOT dan SGPT setelah pemberian paracetamol dosis toksik, dan berdasarkan uji LSD dosis $500 \mathrm{mg} / \mathrm{kg}$ BB memiliki efek yang paling baik terhadap peningkatan kadar SGOT dan SGPT.
\end{abstract}

\section{Kata kunci : Hepatoprotektor, daun galling, SGOT, SGPT, Rattus norvegicus.}

\begin{abstract}
The liver disease is a dangerous disease and still relatively high in Indonesia. One way to determine liver damage by measuring the activity of SGOT and SGPT enzyme. One of the natural substances that potentially have hepatoprotective effects is Galing (Cayratia trifolia L.Domin) and has carried out the result that Galing is potentially containing flavonoids as antioxidants. The purpose of the study is todetermine the effect of hepatoprotective and the effective dose of ethanol extract of Galing leaves rats that induced paracetamol of toxic dose. This type of research is an experimental laboratory, with the design of Completely Randomized Design (CRD) and using 15 rats were divided into 5 groups with three repetitions induced by paracetamol of toxic dose after extract. Based on research data showed that the ethanol extract of galing leaves at a dose of 300,
\end{abstract}


400 , and $500 \mathrm{mg} / \mathrm{kg} \mathrm{BW}$ provide hepatoprotective effect by preventing an increase in SGOT and SGPT after giving paracetamol of toxic dose, a dose of $500 \mathrm{mg} / \mathrm{kg}$ $B W$ have the best effect on levels of SGOT and SGPT.

Keywords : Hepatoprotective, Leaf Galing, SGOT, SGPT, Rattus novergicus.

\section{PENDAHULUAN}

Penyakit hepar di Indonesia umumnya masih tergolong tinggi. Indonesia merupakan negara dengan endemisitas tinggi Hepatitis $\mathrm{B}$, terbesar kedua di Negara Asia Tenggara setelah Myanmar. Berdasarkan hasil Riset Kesehatan Dasar (Riskesdas) tahun 2013, diperkirakan terdapat 28 juta penduduk Indonesia yang terinfeksi Hepatitis B dan C, 14 juta diantaranya berpotensi untuk menjadi kronis, dan dari yang kronis tersebut 1,4 juta orang berpotensi untuk menderita kanker hati (Permenkes, 2013). Penyakit-penyakit yang disebabkan karena kerusakan fungsi hati antara lain hepatitis, sirosis hati, kanker hati, perlemakan hati, kolestatis atau jaundice, hemochromatosis, abses hati, dan tumor hati (Sulistya, 2007).

Penanganan untuk penyakit hepar dapat dilakukan dengan berbagai cara antara lain, dengan memberikan vaksin penyakit hepatitis, menghindari kontak dengan darah atau cairan tubuh yang berasal dari orang lain, serta dapat dicegah dengan mengkonsumsi obat yang berasal dari bahan alam, salah satunya dengan mengkonsumsi obat tradisional. Obat tradisional adalah bahan atau ramuan bahan berupa bahan tumbuhan, bahan hewan, bahan mineral, sediaan sarian atau campuran dari bahan tersebut yang secara turun temurun telah digunakan untuk pengobatan berdasarkan pengalaman (Heyne, 1987).

Pemanfaatan bahan-bahan alam sebagai obat tradisional mulai dikembangkan. Hal ini disebabkan masyarakat menyadari efek samping yang ditimbulkan oleh obat-obat sintetik lebih besar, selain itu juga karena cepat meramunya (mudah dibuat) dan mudah untuk memperolehnya (Wijayakusuma, dkk, 1996). Oleh karena itu obat tradisional merupakan bidang yang masih banyak diminati untuk diteliti. Perkembangan penelitian berjalan cepat sekali, antara lain dipacu oleh beberapa hal seperti diperlukannya 
senyawa-senyawa untuk mengatasi berbagai macam penyakit salah satunya penyakit hepar, dengan menggunakan bahan alam yang bersifat sebagai hepatoprotektif.

Hepatoprotektif (pelindung hati) adalah senyawa obat yang memiliki efek teurapeutik, untuk memulihkan, memelihara, dan mengobati kerusakan dari fungsi hati. Salah satu bahan alam yang berpotensi memiliki efek hepatoprotektor adalah tumbuhan Galing (Cayratia trifolia L. Domin), dan telah dilakukan penelitian bahwa tumbuhan Galing (Cayratia trifolia $\mathrm{L}$. Domin) mengandung senyawa flavonoid, tanin, saponin, triterpenoid, antrakuinon dan alkaloid yang berpotensi sebagai antioksidan (Kumar et al., 2012, Perumal et al., 2012, Widhiana, dkk, 2012). Senyawa antioksidan (flavonoid) dapat menurunkan radikal bebas dan menghambat induksi mediator inflamasi yang berpotensi

\section{METODE PENELITIAN}

Alat yang digunakan adalah Fotometer 5010, pipet mikro, Sentrifuge, Spoit oral $2 \mathrm{cc}$ dan $3 \mathrm{cc}$, menyebabkan kerusakan atau jejak sel hepatrosit (Kurniawan, dkk, 2014).

Selain mengandung senyawa flavonoid yang dapat memberikan efek hepatoprotektor, tanaman Galing (Cayratia trifolia L. Domin) juga mengandung senyawa tanin yang dapat bermanfaat terhadap kesehatan. Tanaman yang mengandung senyawa flavanoid telah terbukti mempunyai aktivitas antioksidan (Alan dan Miller, 1996). Dalam kaitan ini, Ruchi et al., (2007) menyatakan bahwa sebagai tanaman yang mengandung senyawa antioksidan, Galing diduga dapat menghambat terjadinya kerusakan oksidatif pada hati. Batang, daun dan akar memiliki asam hidrosianat dan delphenidin. Selain itu tumbuhan Galing juga berkhasiat sebagai antimikroba, antioksidan, antikanker, antidiabetes, antivirus, dan juga diuretik (Harmanto, 2005).

Spoit injeksi 1 cc, Stop Watch, Tabung sentrifuge, Alkohol 96\%, Aquadest, GPT (ALAT), GOT (ASAT), Paracetamol 2,5 g/kg BB, 
Serbuk Temulawak, Tikus putih (Rattus norvegicus), Daun Galing (Cayratia trifolia L. Domin), Na CMC 0,5\%, dan Na EDTA 10\%.

Penyiapan sampel daun galing dipilih daun galing yang tua (bukan daun yang kuning) daun kelima dari pucuk, dipetik satu persatu secara manual. Kemudian disortasi basah terlebih dahulu, dicuci dengan menggunakan air yang bersih, kemudian diangin-anginkan pada tempat yang tidak terkena sinar matahari langsung yang ditutup dengan menggunakan kain berwarna hitam kemudian simplisia dirajang sesuai bentuk, lalu di keringkan kemudian di sortasi kering dan dilarutkan dengan etanol 96\% kemudian diaduk lalu ditutup dengan penutup wadah kemudian dilapisi dengan menggunakan kain hitam. Kemudian dibiarkan selama 3 hari pada temperature kamar terlindungi dari cahaya. Setelah 3 hari, ekstrak disaring ke dalam bejana wadah penampung yang berwarna gelap kemudian ampas diperas menggunakan kain flannel. Diaduk kemudian disaring lagi sehingga diperoleh ekstrak. Ekstrak yang diperoleh ditutup kemudian disimpan pada tempat yang terlindung dari cahaya selama 2 hari hingga terbentuk endapan, endapan yang terbentuk dipisahkan dari filtratnya. Kemudian filtrat yang diperoleh dikumpul dan diuapkan (dikentalkan) menggunakan alat (Vacuum rotary evaporator). Kemudian hasil dari maserat dibuat dengan berbagai dosis $300 \mathrm{mg} / \mathrm{kg} \mathrm{BB}, 400 \mathrm{mg} / \mathrm{kg} \mathrm{BB}, 500$ $\mathrm{mg} / \mathrm{kg} \mathrm{BB}$.

Penelitian ini didesain dengan metode Rancangan Acak Lengkap, menggunakan 15 ekor tikus putih yang dibagi menjadi lima kelompok sama banyak. Tikus kelompok I diberi Serbuk temulawak selama 6 hari berturut-turut dan diikuti dengan pemberian peracetamol dosis toksik pada hari ke-8 (Kontrol positif). Tikus kelompok II diberi Na CMC $0,5 \%$ selama 6 hari berturut turut dan pada hari ke-8 diberi parasetamol dosis toksik (kontrol negatif). Tikus kelompok III sampai V diberi ekstrak etanol daun galing berturutturut dengan dosis $300 \mathrm{mg} / \mathrm{kg} \mathrm{BB}$; $400 \mathrm{mg} / \mathrm{kg} \mathrm{BB} ; 500 \mathrm{mg} / \mathrm{kg} \mathrm{BB}$; selama 6 hari berturut-turut dan pada hari ke-8 diberi parasetamol dosis 
2,5 g/ kg BB. Pengambilan darah dilakukan 3 kali yaitu pada saat sebelum perlakuan, 6 hari setelah pemberian ekstrak, dan 5 hari setelah pemberian parasetamol dosis toksik.

Darah diambil dengan jalan

\section{HASIL DAN PEMBAHASAN}

Berdasarkan hasil penelitian

Uji Efek Hepatoprotektor Ekstrak penarikan langsung pada intramuscular ekor tikus yang sudah dibius dengan kloroform dengan menggunakan spoit. Darah tersebut kemudian diperiksa kadar SGPT dan SGOT.

trifolia L. Domin) Pada Tikus Putih (Rattus norvegicus) diperoleh hasilnya pada tabel berikut:

Etanol Daun Galing (Cayratia

Tabel 1. Rata - rata Hasil Pengukuran Kadar SGOT dan SGPT Darah Tikus Putih Setelah Pemberian Ekstrak Daun Galing dan Setelah Induksi Paracetamol

\begin{tabular}{cccccc}
\hline \multirow{2}{*}{ No } & Perlakuan & \multicolumn{2}{c}{$\begin{array}{r}\text { Kadar Setelah Pemberian } \\
\text { Ekstrak }(\mu / \mathrm{l})\end{array}$} & \multicolumn{2}{c}{$\begin{array}{r}\text { Kadar Setelah Pemberian } \\
\text { Paracetamol }(\mu / 1)\end{array}$} \\
\cline { 3 - 6 } & & SGOT & SGPT & SGOT & SGPT \\
\hline 1 & $\begin{array}{c}\text { Serbuk temulawak } \\
\text { (kontrol positif) }\end{array}$ & 24,33 & 19,67 & 31 & 20 \\
\hline 2 & Na CMC (kontrol negatif) & 39,67 & 38,67 & 75,33 & 65,33 \\
\hline 3 & Ekstrak 300 mg & 29,33 & 29 & 65,67 & 32 \\
\hline 4 & Ekstrak 400 mg & 27,67 & 29,33 & 47 & 28 \\
\hline 5 & Ekstrak 500 mg & 26 & 23 & 38,33 & 23,33 \\
\hline
\end{tabular}




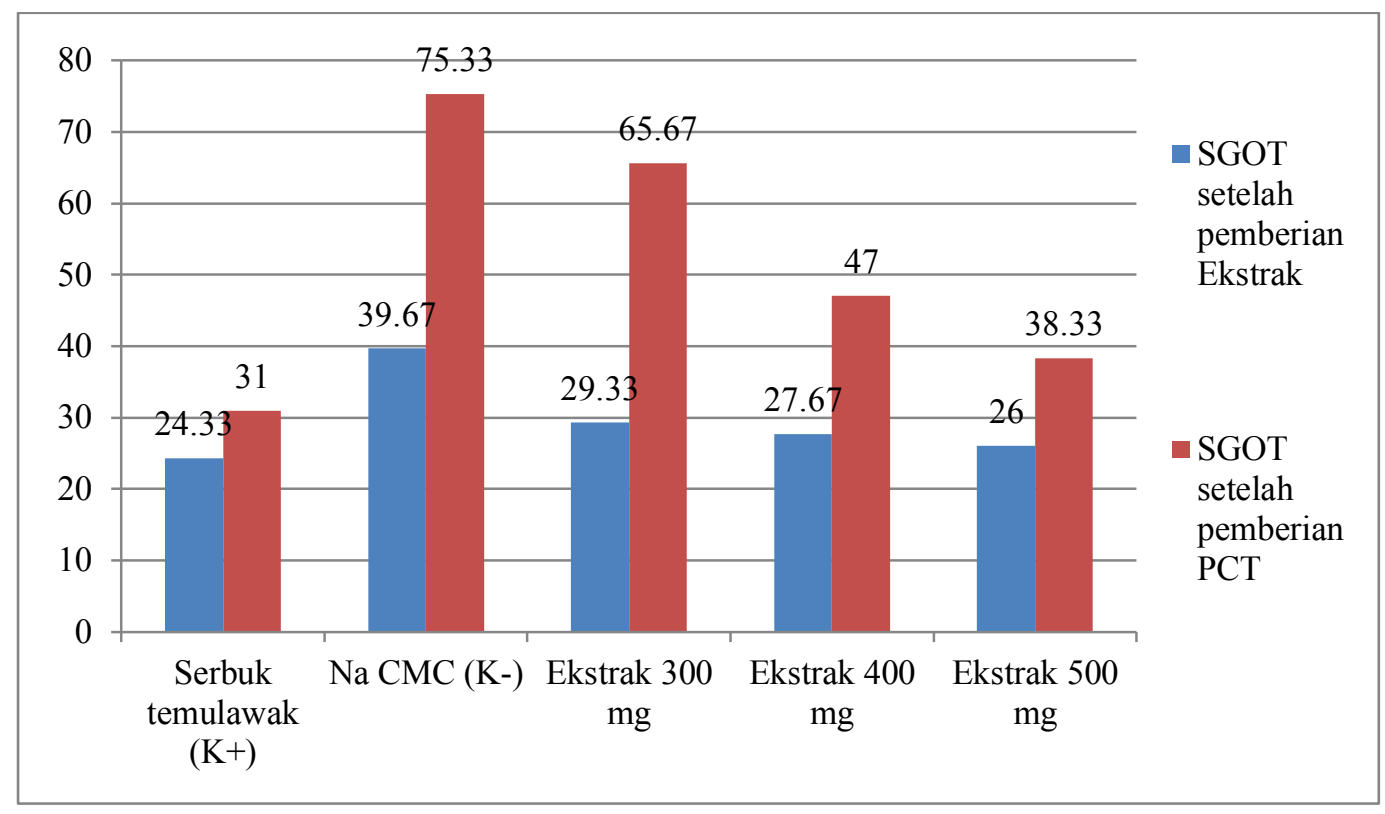

Gambar 1. Diagram Enzim SGOT $(\mu / 1)$ tikus putih setelah pemberian ekstrak dan setelah induksi Paracetamol

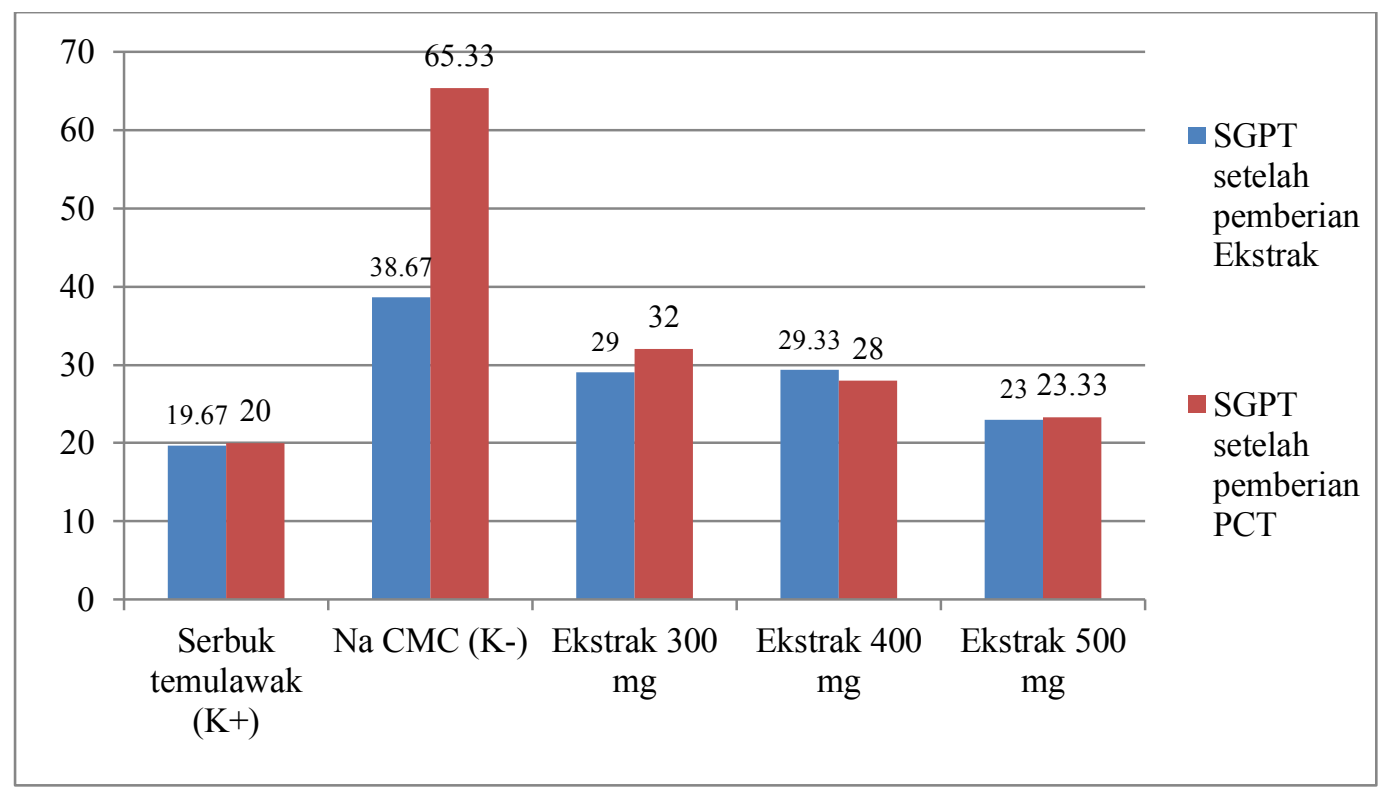

Gambar 2. Diagram Enzim SGPT $(\mu / 1)$ tikus putih setelah pemberian ekstrak dan setelah induksi paracetamol

Dari data hasil pengamatan terhadap pengukuran kadar enzim
SGOT dan SGPT setelah pemberian ekstrak etanol daun galing (Cayratia 
trifolia L. Domin) menunjukkan adanya kenaikan kadar enzim SGOT dan SGPT dari semua konsentrasi yang diberikan serta kontrol positifnya kecuali dengan kontrol negatif yang tidak mengalami kenaikan kadar enzim SGOT dan SGPT. Hal ini berarti bahwa ekstrak etanol daun galing dapat memperbaiki dan mempercepat selsel hati yang rusak. Dari Tabel 2 juga dapat dilihat bahwa semakin tinggi dosis praperlakuan ekstrak etanol semakin besar daya hambat kerusakan sel hati yang ditandai dengan penurunan kadar SGPT dan SGOT dalam darah tikus seiring dengan peningkatan dosis yang diberikan.

Aktivitas hepatoprotektif yang ditunjukkan oleh ekstrak etanol daun galing kemungkinan disebabkan oleh adanya aktivitas antioksidan dalam tanaman tersebut. Dalam hal ini, aktivitas antioksidan tersebut terjadi karena adanya senyawa flavanoid dalam tanaman galling, flavonoid diduga berpengaruh dalam menghambat kerusakan hati dengan cara mengikat radikal bebas sehingga dampaknya terhadap hati berkurang.
Hasil penelitian ini telah menunjukan bahwa kadar SGOT dan SGPT kelompok tikus yang diberi ekstrak daun galing kemudian dipapar paracetamol tidak setinggi kelompok tikus yang tidak diberi ekstrak daun galing. Oleh karena itu pemberian ekstrak daun galing terbukti secara signifikan melalui statistik mempunyai aktivitas hepatoprotektif terhadap hati tikus yang dipapar paracetamol dosis toksik.

Hasil statistik menunjukkan perbedaan hasil yang signifikan dari pengujian kadar SGOT dan SGPT, dimana ekstrak daun galing memiliki efek terhadap kadar SGOT tetapi efeknya tidak sama dengan kontrol positif sedangkan untuk kadar SGPT dosis $400 \mathrm{mg} / \mathrm{kg}$ BB dan $500 \mathrm{mg} / \mathrm{kg}$ BB dapat memberikan efek yang sama dengan kontrol positif dalam penurunan kadar SGPT. Tetapi kita kembali kepada enzim itu sendiri, dimana enzim SGOT tidak spesifik terhadap kerusakan sel hati karena enzim SGOT juga terdapat pada otot jantung, otot tubuh, ginjal dan pankreas, sedangkan enzim SGPT sangat spesifik terhadap sel-sel hati. 
Dimana penentuan aktivitas ALT atau SGPT dianggap sebagai tes yang lebih sensitive dan spesifik terhadap adanya kerusakan hepatoseluler akut, sedangkan aktivitas AST atau SGOT akan menjadi lebih tinggi apabila terdapat nekrosis jaringan yang lebih hebat. Jadi, apabila ekstrak daun galing dapat menurunkan kadar SGPT sudah dikatakan bersifat sebagai hepatoprotektor.

\section{KESIMPULAN}

Dari hasil penelitian yang dilakukan dapat disimpulkan bahwa Ekstrak etanol daun galing (Cayratia trifolia L.Domin) dengan dosis 300 $\mathrm{mg} / \mathrm{kg} \mathrm{BB}, 400 \mathrm{mg} / \mathrm{kg} \mathrm{BB}$, dan 500 $\mathrm{mg} / \mathrm{kg} \quad \mathrm{BB}$ memberikan efek hepatoprotektor pada tikus putih yang diinduksi Paracetamol dosis toksik

Dosis $500 \mathrm{mg} / \mathrm{kg}$ BB dari ekstrak daun galing memberikan efek hepatoprotektor yang efektif pada tikus putih yang diinduksi paracetamol dosis toksik.

\section{DAFTAR PUSTAKA}

Afifah dkk. 2003. Tanaman Obat Untuk Mengatasi Hepatitis. Jakarta : PT Agro Media Pustaka.
Alan, L. dan N. D. Miller. 1996. Antioxidant flavonoids: Structure, function and clinical usage. Alt. Med. Rev. 1(2):103-111.

Anonim. 2009. Kamus Kedokteran. Jakarta : Widyatamma.

Dalimartha, S. 2007. Atlas Tumbuhan Obat Indonesia. Bogor : Trobus Agriwidya

Gunawan Gan Sulistya, 2007. Farmakologi dan Terapi. Jakarta : Fakultas Kedokteran, UI.

Gupta J, Kumar D, Gupta A. 2012. Evaluation of gastric antiulcer activity of methanolic extract of cayratia trifolia in experimental animals. Asian Pac J Trop Dis 2012;2:99102

Goodman \& Gilman. 2007. Dasardasar Farmakologi Terapi. Jakarta: EGC

Kanchana, dan Muh.Sadiq. 2010. Hepatoprotective Effect Of Plumbago Zeylanica On Paracetamol Induced Liver Toxicity In Rats. International Journal of Pharmacy and Phar $\backslash$ maceutical Sciences.

.Kumar, D., Gupta, J., Kumar, S., Arya, R., Kumar, T. and Gupta, $\quad$ A., 2012, Pharmacognostic Evaluation of Cayratia trifolia (Linn.) Leaf, Asian Pacific Journal of Tropical Biomedicine, 2:6-10. 
Kurniawan, Jefri., Bangsawan, Indra, Pandu., dan Andriani., 2014. Uji efek Hepatoprotektor ekstrak etanol Daun lidah buaya (Aloe vera $\mathrm{L}$ ) terhadap kadar malondialdehid plasma tikus jantan galur wistar yang diinduksi paracetamol. Vol. 8 No. 6.

Lu, F.C. 1995. Toksikologi Dasar; Asal, Organ Sasaran dan Penilaian Resiko Edisi ke Dua. Jakarta : UI Press.

Latu, Jeane. 1990. Gastroenterologi Hepatologi. Bandung : PT Alumni Bandung.

.Morton, G.M. 2005. Panduan Pemeriksaan Kesehatan. Jakarta : Buku Kedokteran EGC.

Noer, S. 1990. Gastroenterologi Hepatologi. Jakarta : CV. Sagung Seto.

Noer, S dkk. 1996. Buku Ajar Ilmu Penyakit Dalam Edisi III. Jakarta : UI Press.

Ongi, J. 2011. Cayratia trifolia. (Online). Tersedia http://translate.googleuser. Content.com/2012/05/05/cayr atia-trifolia.(07 januari 2016).

Plaa, G.L dan Charbonneau, M. 2001. Principles and Methods of Toxicology. Philadelphia : Taylor and Francis.
Perumal PC, Sophia D, Raj CA, Ragavendra P, Starlin T, Gopalakrishnan VK. In vitro antioiesxidan activities and HPILC analysiscof ethanolic extract of Cayratia trifolia (L). Asian Pac J Trop Dis 2012;2:S952-6.

Restiani, A.R., Suhadi, Tuarita, H. 2013. Keanekaragaman Tumbuhan Liani di Hutan Musim Blok Curah Jarak Taman Nasional Baluran. Universitas Negeri Malang. Press : Jawa Timur.

Ruchi, G.M., O.F. Majekodunmi, M. Ramla, B.V. Gouri, A. Hussain, dan S.B. Suad. 2007. Antioxidant capacity of some edible and wound healing plants in Oman. Food Chem. 101:465-70. Shivayogi, P.H, K. Rudresh, B.

Soemohardjo, S dkk. 1982. Tes Faal Hati. Bandung : PT Alumni

Smith, JB, Mangkoewidjojo, S. 1988. Pemeliharaan, Pembiakan dan Penggunaan Hewan Percobaan di Daerah Tropis. Jakarta : UI Press.

.Zimmerman, H.J. 1978. Hepatotoxicity. New York : Apleton, Century Crofts. 